\title{
The Effect of Fit between Manufacturing Strategy, Strategic Orientation, and Marketing Strategy on Business Performance
}

\author{
"Yue-Yang Chen ${ }^{1}$ \\ I-Jen Wu $\mathbf{u}^{2}$ \\ I-Chen Tsai ${ }^{2}$ \\ 'Dept. of Businesss Admininistration, I-Shou Iniversity, Thiiwiall

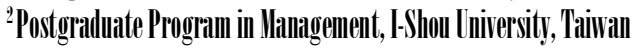

\begin{abstract}
As the world has become closer and increasingly connected, business competition becomes more aggressive. As a result, marketing which has evolved for decades becomes so vital that no company can survive without it. Though marketing strategy and manufacturing strategy are organizationally separate in most firms, without a coordination of these two functional entities, an organization's survival in the market could potentially be jeopardized. Research has proved that these dimensions have a significant impact on organizational performance. Yet there is very little research being done from a holistic perspective in examining the fit relationship between marketing, manufacturing, and business strategy. Therefore, this research tries to look at those dimensions from a fit as covariation perspective. A fit model was proposed and exemplified using empirical data collected from Taiwan's top ranking companies in the manufacturing and service industry. Findings showed that the fit between marketing strategy, manufacturing strategy, and strategic orientation has a significant and positive effect on organizational performance.

Keywords: Fit, marketing strategy, manufacturing strategy, strategic orientation, fit as covariation

JEL : L69, M31
\end{abstract}

Marketing usually acts as the channel of communication between the marketing environment, and customer preference and usually deals with revenue maximization, whereas manufacturing usually is responsible for receiving the design for production and cost minimization (Brooksbank, 1991; Lilien and Weinstein, 1984). However, marketing and manufacturing are organizationally separated in most firms (Karmarkar and Lele, 2005; Jüttner, Christopher and Godsell, 2010). Therefore, the strategic alignment between marketing and manufacturing strategy is a crucial issue for academic study and empirical practice. A fact in most companies is that the great bulk of the assets used, the capital invested, the people employed, and management time, are on the operation side in a firm. It is apparent that the manufacturing is an indispensable constituent in the success of an organization as a whole. Ever since Skinner's famous work 
back in 1969, manufacturing strategy has been under the spotlight from researchers in related fields. The definition of manufacturing strategy was stated by Skinner as "a company's competitive strategy at a given time places particular demands on its manufacturing function, and, conversely, that the company's manufacturing posture and operations should be specifically designed to fulfill the tasks demanded by strategic plans" (Skinner, 1969). As he pointed out in another work in 1974, no company can perform well on every yardstick. An organization can only outperform its competitor by focusing on a narrow product mix for a particular market niche with the premises that each of its key functional area (e.g., marketing, manufacturing, sales...etc.) in operation activities must have the same objective (Skinner, 1974). In addition, the type of manufacturing strategy used by a firm must comply with its chosen competitive strategy (Amoako-Gyampah and Acquaah, 2008; Sun and Hong, 2002). Consequently, strategic orientation of a business should be in line with manufacturing and marketing strategy.

It is widely recognized that the use of contingency theory is a strategy that most organizations adopt toward a competitive environment that varies on a minute-by-minute basis. Strategic alignment (or fit) is considered as the central thrust in many management disciplines, especially in the field of strategic management (Delery and Doty, 1996; Venkatraman, 1989a). Doty, Glick and Huber (1993) demonstrated that increased organizational effectiveness is driven by the internal consistency or 'fit' between the various patterns of relevant contextual, structural, and strategic factors. Organizational performance is usually determined by how effectively the organizational structure is being implemented, and that depends on how the functional entities are being organized (Mintzberg, 1979; Ward, Bickford and Leong, 1996). In other words, through coordinating subsystems within the organization with a variety of different strategies, superior organizational performance can be achieved (Venkatraman, 1990).

Generally, the strategy is rooted as a concept to match or align organizational resources with environmental opportunities and threats on an ongoing basis (Venkatraman and Camillus, 1984). Although many studies have either implicitly or explicitly employed the concept of fit, it occupied a central role in strategic management. Theories vary widely in subject matter, they share the common proposition that an organizational outcome is the consequence of strategic alignment between two or more factors or 


\section{Chen et al.}

dimensions (Van de Ven and Drazin, 1985). In addition, according to Venkatraman (1990) and Green Jr. et al. (2015), marketing, and manufacturing reflect two important functional spheres, namely, operations and selling, while the strategic orientation captures the "generic typologies" of organizations. An effective strategy of a business is one that collectively reflects consistency or coherence among these three dimensions mentioned above. Weir et al. (2000) indicated that companies must have the correct alignment of manufacturing and marketing strategies to achieve the success for equipping and managing to manufacture as a competitive weapon. Tang (2010) also mentioned without coordinating with the operations area, an excellent marketing plan for offering products and services that meet customer needs could result in disappointment. It means that the improvement of efficiency in manufacturing can be realized by creating and maintaining enterprise-specific resources and capabilities, which lead to a competitive advantage and differentiate the enterprise from their competitors, and vice versa (Dombrowski et al., 2016).

Moreover, due to the concept of strategic alignment has not been adequately clarified when employed in the various social science streams (Venkatraman and Camillus, 1984), the above mentioned strategic alignment of three constructs is needed. For example, by using a qualitative literature review approach to identify key contributions to marketing- manufacturing alignment area and incorporate them into the theoretical background, Sombultawee and Boon-itt $(2018$, p. 8) indicated that "...It is further limited in that the weakness of empirical literature on marketing-operations alignment." Based on review and evaluation of previous studies, Hitt, $\mathrm{Xu}$ and Carnes (2016) identify the issues in the research and highlight some exemplary research themes in the use of resource based view (RBV) in operations management. They suggest that further application of RBV to explain the importance of fit between marketing and manufacturing can add richness in operations management research field.

Consequently, the general purpose of this study is to contribute to the theory and practice, and studying strategic alignment by pursuing several specific objectives. First, this study tends to shed more light on manufacturing related strategic alignment research to reflect the simultaneous and holistic pattern of interlinkages between manufacturing strategy and other strategies, which refers to marketing strategy and strategic orientation. Second, it intends to provide further insights into performance implications within the 
broad conceptualization of fit between marketing strategy, manufacturing strategy, and strategic orientation. Finally, it examines strategic alignment by using fit as covariation to echo its verbal and statistical correspondence of research.

\section{LITERATURE REVIEW}

Fit

The central theme of fit is generally understood in its metaphoric form, and it is common for theorists to postulate relationships using words and phrases such as matched with, contingent upon, consistent with, congruence, or alignment (Venkatraman, 1989b). The concept of fit has served as an important building block for theory construction in several areas of research (Aldrich, 1979; Van de Ven and Drazin, 1985). In general, the idea is the efficient alignment of organizational resources and capabilities with environmental opportunities and threats (Andrews, 1980; Bourgeois, 1980; Schendel and Hofer, 1979) or it can be seen as a match between (or among) a set of theoretical dimensions (Venkatraman, 1990). It is important from two perspectives in the organizational theory literature: descriptive and normative. The descriptive perspective specifies the existence of relationships among a set of theoretically-related variables without any explicit linkage to performance. The normative perspective develops an explicit link between co-alignment and performance (Venkatraman, 1990). Venkatraman and Camillus (1984) made an initial attempt to distinguish between the 'content of fit' and the 'pattern of interactions'. Co-alignment is between strategy and one or more relevant constructs in the former perspective. The invocation of fit is external to the definition and operationalization of strategy. The latter perspective holds that strategy is not viewed as a concept that is separable from the conceptualization of fit; co-alignment is intrinsic to the conceptualization and operationalization of strategy itself. Grant and King (1982) proposed that strategy is a timed sequence of internally consistent allocations of resources to achieve an organization's objectives (Venkatraman, 1989a); internal consistency refers to the co-alignment among decisions in key areas of operations and functions. Gupta (1988) also proposed basic propositions that link strategy and managerial characteristics with explicit linkages to performance.

\section{Manufacturing Strategy}




\section{Chen et al.}

As academics gradually picked up interest on the importance of manufacturing strategies, research in the field has increased significantly over the past decades. Research in manufacturing strategies has focused on the alignment of strategic priorities and its impact on performance, let along the importance of the alignment between strategies. The strategic view of manufacturing strategy dates back to Harvard in the 1940s and 1950s where researchers observed different ways companies chose to compete within different industries (Voss, 1995). With Skinner's contribution in "manufacturing-missing link in corporate strategy" and "the focused factory" which not only set out the importance of explicit linkages between manufacturing choices, a firm's environment, and corporate strategy but also developed the concepts of focus and of internal and external consistency (Voss,1995). Wheelwright (1984) also supports the idea that the manufacturing strategy should be in alignment with business strategy.

Manufacturing strategy process, content and implementation determine how resources and capabilities are to be deployed within organizations to complement the business strategy (Hayes and Wheelwright, 1984). The major benefit of manufacturing strategy is that it provides a means for focusing the attention of corporate management on manufacturing concerns (Leong and Ward, 1994). Manufacturing strategy content embodies the choices of the most beneficial set of manufacturing capabilities for a business unit and the investments needed to build that set of capabilities (Ward et al., 1996). Manufacturing capability is regarded as a stock of strategic assets which are accumulated through a pattern of investment over time. It cannot be easily imitated or acquired by trade, nor can good substitutes be found (Ward et al., 1996). Manufacturing strategy provides a competitive weapon in the organization's strategic planning if utilized properly (Skinner, 1969). Besides, different manufacturing strategies translate into different supply management practices (Rebolledo and Jobin, 2013).

\section{Marketing Strategy}

Marketing strategy is a set of integrated decisions and actions (Day, 1990) by which a business expects to achieve its marketing objectives and meet the value requirements of its customers (Cravens, 1999). As organizations only have limited resources, market segmentation and targeting is a necessity for firms to commit limited resources only to satisfy a certain particular customer group. Marketing orientation 
considered by many as a measure of the behaviors and activities that reflects the marketing concept (Hunt and Lambe, 2000). However, marketing is not only a strategy or a concept but a philosophy that is a cornerstone of successful firm's cultures (Hunt and Lambe, 2000). A concept that could lead firms to better understand and meet the needs of their target customer group by putting customers at the center of the firm's operation and strategy formulation (Deshpande and Webster,1989).

\section{Strategic Orientation}

There can be little doubt that, by developing a business strategy, the organization determines how a strategic business unit (SBU) supports organizational goals, competitive direction, and its scope as well as determining how it will seek competitive advantages (Garvin, 1993). The business strategy represents the way that a business positions itself about its competitors, and how it confronts the future challenges. Without a strategy, an organization might find itself in a dilemmatic situation of conflict between its short-term decisions and long-term goals (St John and Young, 1992). Business strategy is the outcome of complex processes of decisions made to guide an organization concerning the environment, structure, and processes that influence its organizational performance (Croteau and Bergeron, 2001). Miles and Snow (1978) identified four archetypes of how firms address their market domains and construct structures and processes to achieve success. Prospectors continuously seek to locate and exploit new product and market opportunities while Defenders attempt to seal off a portion of the total market to create a stable set of products and customers. Analyzers occupy an intermediate position between the two extremes by combining the strengths of both the Prospector and Defender to cautiously follow Prospectors into a new product. The Reactor does not have a consistent response to the entrepreneurial problem.

\section{-Theoretical Framework / Hypothesis}

The argument of calling for cross-functional collaboration has some history. This argument is put forth by the resource based view (RBV), where the task of every organization is to create distinctive, inimitable competencies based on combinative firm resources (Barney, 1986, 1991; Penrose, 1959; Wernerfelt, 1984). As the discipline and practice of marketing has been undergoing a period of metamorphosis over the last four decades (Varadarajan, 1999). As theory is developed, knowledge enhances and spawns new questions 


\section{Chen et al.}

requiring different explanations demanding even greater advances in knowledge; the role of marketing nowadays has become one of the key functional entities within the firm. For more than forty years, the marketing concept has been considered the cornerstone of marketing, which is highly strategic in nature (Hunt and Lambe, 2000). Jaworski and Kohli (1993) also pointed out the marketing concept was an important antecedent to business success.

The contributions of modern business strategy have come from a broad range of disciplines, and the study of manufacturing is an indispensable part. Sun's study has produced the result that only when the manufacturing strategy and business strategy are in alignment, manufacturing contribute to the improvement of business performance and business objectives can be achieved (Sun and Hong, 2002). Manufacturing strategy is linked to business strategy through market requirements (Hill, 1985), and market requirements are crucial to manufacturing strategy (Pagell and Krause, 1999) because order-qualifying and order-winning criteria win orders from customers (Hill, 1995). Since, manufacturing strategy becomes aligned to the external environment when business and manufacturing strategies are linked (Corbett and Van Wassenhove, 1993; Garvin, 1993; Schendel and Hofer, 1979; Ward and Duray, 2000), manufacturing strategy should involve in strategic orientation and implementation (Kim and Lee, 1993; McDougall, Deane and D'Souza, 1992). In response to the speed of change in the hypercompetitive external business environment, strategists especially advocate that manufacturing and marketing work together to speed up and improve the quality of strategic decision making (Brown and Eisenhardt, 1998; D’Aveni, 1994). For a firm, its operational efficiency is usually dependent on well-managed operations, while its effectiveness depends on well-administrated marketing (Bateson and Hoffman, 1999, Dombrowski et al., 2016). In particular, it has been proposed that aligning marketing and manufacturing strategies can make a company more responsive to changing customer demands and market vibrations. However, although aligning manufacturing and marketing has been a much talked about subject in recent years in both academic and trade publications, little empirical research has been conducted to test their fit relationships complying with strategic orientation within the firms in explaining the performance.

Consequently, while a specific competitive strategy itself does not have significant effects upon 
performance, its linkage and interaction with the functional level strategies has significant performance effects (Sombultawee and Boon-itt, 2018). This leads to the assumption that marketing strategy, manufacturing strategy, and strategic orientation must be in line with each other to optimize the organizational outcome, hence the following hypothesis is proposed:

$\mathrm{H}$ : Fit among manufacturing strategy, marketing strategy, and strategic orientation has a significant and positive direct effect on business performance, in terms of growth and profitability.

\section{METHODOLOGY}

\section{Scale Development}

There are three constructs being measured in this study: manufacturing strategy, marketing strategy, and strategic orientation. Fit, the fourth construct, is a latent variable being contributed by the three strategies mentioned above. A multi-item method was used to construct the questionnaires. Five-point Likert type format was used for each item ranging from 1 "strongly disagree" to 5 "strongly agree".

Marketing involves satisfying consumers' needs and wants. The task of any business is to deliver customer value at a profit (Kotler et al., 2006). Marketing strategy is a set of integrated decisions and actions (Day, 1990) by which a business expects to achieve its marketing objectives and meet the value requirements of its customers (Cravens, 1999). In the research proposed by Slater and Olson (2001), they identified various distinct strategic behavioral patterns of marketing strategy by using these attributes. The sample items for measuring this construct include "our company systematically learns about customers", "our company focuses marketing activities on specific segments", and "our company provides products/services with a low probability of failure".

According to Skinner (1969), manufacturing strategy refers to a company's competitive strategy at a given time and places particular demands on its manufacturing function, and, conversely, that the company's manufacturing posture and operation should be specifically designed to fulfill the tasks demanded by strategic plans. Drawing on Miller and Roth (1994), the measurement scale for manufacturing strategy is 


\section{Chen et al.}

cited. The sample items are "our company makes rapid design changes and/or introduce new product quickly", "our company offers consistent quality", and "our company delivers products quickly".

Strategic orientation refers to how firms and organization compete in an industry or market (Varadarajan and Clark, 1994). The measurement scale was adapted from Sabherwal and Chan's (2001) instrument and composed of 18 items rated by the respondents. The sample items are "our business develops strong relationships with our suppliers", "our business tends to be number-oriented and analytical in our operations", and "our business decisions generally follow tried and true paths".

Business performance is defined as the measure of growth and profitability of the firm through its business endeavors and deployment of organizational and technological resources. It was operationalized using Venkatraman's (1989b) instrument to measure it from a multi-dimensional perspective. The respondents were asked to indicate on 7-point Likert format consisting 9 items about their perceptions on how his or her firm performed relative to the main competitor in the market on two dimensions (i.e., growth and profitability) in term of sales growth rate, market share gains, ROI, net profit, return on sales, and financial liquidity. The sample items are "the sales growth position has been outstanding relative to competition", "the return of corporate investment has been outstanding relative to competition", and "the financial liquidity position has been outstanding relative to competition".

\section{Sample and Data}

Primary data were collected through a cross-sectional mailed survey. Mailing lists were pooled from the China Credit Information Service (CCIS), which includes the top 5000 companies in the manufacturing industry and top 500 companies in service industry in Taiwan. Those companies were being chosen for being the best performing companies in Taiwan within the field. Once the mailing list was obtained, questionnaires with accompanying cover letters and a preprinted 'freepost' return envelope (Dillman, 1978) were distributed to companies being selected using a simple random sampling method. Two weeks later, each recipient was sent a reminder postcard. Four weeks after the initial mailing, a follow-up letter and questionnaire were sent to all eligible subjects again who had not yet returned the questionnaire. A total of 
1,298 questionnaires were mailed to the selected companies.

To assess the presence of non-response bias in this empirical data, early and late respondents were compared in terms of key attributes: gender, seniority, post, and the scales (employees) of firms. The results showed that there was no significant difference between the two groups in relating to these characteristics.

\section{Sample Characteristics}

Out of the 1,298 questionnaires that were distributed, 78 of responders were out of reach, which reduced the number in the sample list to 1220 . By the termination of data collection, overall, a total of 148 surveys had been returned. Among the 148 respondents, only 141 of them were valid. Thus, the gross response rate was 11.55 percent (141/1220*100). 115 out of the 141 respondents came from the manufacturing industry; others were from the service industry. Most of the respondents appeared to be males in their forties, and since the target respondents of our questionnaire were middle or senior executives, most of the respondents had attained the seniority of over ten years. The primary respondents of our questionnaires came from middlescaled organizations with employees between 100 to 500 people.

\section{RESULTS}

\section{Measurement Model}

To consolidate the relationship among properties of the measures, the research model assessment analysis was conducted using Partial Least Square (PLS). As shown in Table 1 (see Appendix-I), the poor loading of Product Line Breadth (PLB) and Premium Pricing (PP) implied that those two properties were not necessary constituent of marketing strategy. Therefore those two properties were dropped to ensure the unification of the entire construct. After dropping out poor loading properties, model was being re-estimated with Confirmatory Factor Analysis (CFA) model. Consequently, the loadings for each item were ranged from 0.54 to 0.96 demonstrating a good explanation for its construct, and composite reliability coefficient for each construct is greater than recommended value of 0.60 (Fornell and Lacker, 1981).

Furthermore, the value of Average Variance Extracted (AVE) can be used to discern convergent validity 


\section{Chen et al.}

(Fornell and Larcker 1981; Hair et al., 2006). Variance extracted estimate can also be used to assess the average variance extracted for all constructs, suggesting that a value of 0.50 or larger is adequate. As can be seen in Table 1, all of the values met the criteria, demonstrating a reasonable degree of convergent validity. In addition, according to Fornell and Larcker (1981), discriminant validity of the construct was assessed by the variance extracted test. Variance extracted estimates for any pair of two factors were compared to the square of the correlation between the two constructs. Discriminant validity is supported if both variance extracted estimates are greater than the squared correlation. The result (shown in Table 2, see Appendix-II) shows that this research appeared to have fine discriminant validity since each squared correlation is less than both applicable variance extracted estimates.

\section{Hypothesis Testing}

The structural model is evaluated by using path coefficients estimated by PLS. The mean value of reliable items in each variable was taken to create a second-order construct for use in the assessment of the structural model. Each variable was then defined by reflective indicators measured by those corresponding constructs. Reflective indicators indicate the underlying construct and also contribute to the construct explanation since they co-vary simultaneously. Study hypothesis tested whether the strategic alignment between manufacturing strategy, marketing strategy, and strategic orientation has a significant and positive direct effect upon business performance. A positive and significant relationship was observed between strategic alignment among constructs and organizational performance as depicted in Figure 1 (see Appendix-III). The result indicates that a positive and significant fit relationship was observed between manufacturing strategy, marketing strategy, and strategic orientation upon business performance, in terms of growth and profitability. Thus, the hypothesis $(\mathrm{H})$ is supported.

\section{DISCUSSION}

This research seeks to contribute to the literature in the field of strategic alignment. To resume with the preceding discussion, the results of this research show that the strategic alignment among marketing strategy, manufacturing strategy, and strategic orientation has a positive and significant effect on the 
business performance. In this vein, the results of this research have important implications for both research and practice.

\section{IMPLICATIONS}

Regarding to research, this study has built upon prior knowledge suggesting a positive relationship between strategic alignment and business performance. By extending the research, we have further examined the effects of strategic alignment between three distinctive constructs, namely, marketing strategy, manufacturing strategy, and strategic orientation, to business performance. The results of the research suggest that all three constructs play an important contributing role in business performance. The findings of present research are consistent with that of Rhee and Mehra (2006), showing that the performance effect of strategic integration between the competitive strategy, operations and marketing activities significantly affects the relationship of key activities of operations and marketing with business performance. In addition, consistent with Da Silveira (2005), O'Leary-Kelly and Flores (2002), and Rho, Hahm and Yu (1994), our findings also support the fact that in order to improve the linkage between marketing and manufacturing strategies, greater communication between functions, increased coordination mechanisms and a good understanding of the trade-offs based on capabilities, sharing market knowledge within a firm, then the higher performance will be achieved.

In order to attain maximum benefits for the organization, it is very important to analyze and design strategies from a holistic perspective. Though, there has been much theorizing in the areas of marketing, manufacturing, and strategic orientation, to the best of our knowledge, no research has assessed these constructs using a holistic perspective. We hope present research can be regarded as a base study for ones who are interesting in this research field.

The results show that all three constructs can have a strong impact on business performance. It is important to know that alignment pays off under certain conditions. Though constructs being proposed in this research are studied extensively, inter-functional coordination has received scant attention in strategy implementation research, as indicated by Olsen, Slater and Hult (2005). It is still a challenge for most companies to attain a fine degree of inter-functional coordination, and volatile as the real world situation is, 


\section{Chen et al.}

problems could be much more complicated than expected. Therefore, the results of the research only functioned as a principle while applying to the real deal. To maximize the benefits to the organization, internal cooperation should be taken into consideration while putting into practice.

Marketing based decisions include both product development and marketing planning, whereas, manufacturing based decisions involve both process development and manufacturing planning decisions. Traditionally, the objectives and strategic decision areas between marketing strategy and manufacturing strategy are different, resulting in a contradictory direction for explaining the performance criteria. While the efficiency of a service organization is usually dependent on well-managed operations, its effectiveness depends on well-administered marketing. Thus, the functional integration (i.e., fit) between marketing and manufacturing should be taken into account to enable the factory to respond quickly and economically to dynamic market changes, thereby ensuring value creation for the customer (Piercy, 1995). For doing so, for example, some simpler tools can be employed for developing the marketing strategy, as well as to improve cross-functional cooperation between design and manufacturing during the product development process (Weir et al., 2000). Another way to enhance the fit between marketing and manufacturing is the use of crossfunctional teams. As Katzenbach and Smith (1993) pointed out, companies who used cross-functional teams also identified common goals, shared objectives, and communication as being important. Thus, the fit between the functional departments will be more coherent and concrete.

\section{LIMITATIONS AND FUTURE DIRECTIONS}

The strength of this research lies in the realism of the sample and study context. However, this is also a source of certain limitations. So volatile the external environments have become, it is impossible to sculpt a general pattern to function effectively under any circumstances. Therefore the result of this research only serve as a rule of engagement. Other external factors could come to affect the result of this research's practice. Also, due to the financial limitation of the research, care must be taken while a single informant approach was adopted and the consequence it might bring. The sample population is based on approximately 1000 manufacturing and 300 service respondents in Taiwan. The result should not be generalized to those subjects with markedly difference comparing the research. 
International Journal of Management, Economics and Social Sciences

To extend the scope of the research, future research may assess the relationships of constructs proposed utilizing multiple perspectives such as those mentioned in the earlier chapters, or by employing different constructs depending on the features of the subject industry. As Van de Ven and Drazin (1985: 358) stated: "Studies should be designed to permit comparative evaluation of as many forms of fit as possible". Future research could further assess the relationships between constructs using the reductionist approach. In the similar vein, the weight of each construct contributing to the business performance is also an important consideration that should be aware of from a practical perspective, especially for those who might consider exercising the model in the real world base.

While this research only adopts a two industries context, respectively manufacturing and service, a multiindustry sampling approach could be exercised to increase the generalizability of the findings.

\section{REFERENCES}

Aldrich, H. (1979). Organizations and environments. New Jersey: Prentice Hall.

Amoako-Gyampah, W. \& Acquaah, M. (2008). Manufacturing strategy, competitive strategy, and firm performance: an empirical study in a developing economy environment. International Journal of Production Economics, 111, 575-592.

Andrews, K. R. (1980). The Concept of Corporate Strategy. Illinois: Anderson Publish.

Barney, J. B. (1986). Strategic factor markets: expectations, luck, and business strategy. Management Science. 32(10): $1231-1241$.

Barney, J. B. (1991). Firm resources and sustained competitive advantage. Journal of management. 17(1): 99-120.

Bateson, J. E. \& Hoffman, K. D. (1999). Managing service marketing. New York: The Dryden Press, Harcourt Brace College Publishers.

Bourgeois, L. J. (1980). Strategy and environment: a conceptual integration. Academy of Management Review, 5, 22-39.

Brooksbank, R. (1991). The essential characteristics of an effective marketing plan for the 1990s. Marketing Intelligence and Planning. 9(4): 17-21.

Brown, S. L. \& Eisenhardt, K. M. (1998). Competing on the edge: Strategy as structured chaos. Boston: Harvard Business School Press. Corbett, C. \& Van Wassenhove, L. (1993). Trade-offs? Competence and competitiveness in manufacturing strategy. California Management Review. 35(4): 107-120.

Cravens, D. (1999). Strategic marketing (6th ed.). Boston: McGraw-Hill.

Croteau, A. M. \& Bergeron, F. (2001). An information technology trilogy: Business strategy, technological deployment and organizational performance. Journal of Strategic Information System, 10, 77-99.

D’Aveni, R. (1994). Hypercompetition. New York: The Free Press.

Da Silveira, G. J. C. (2005). Market priorities, manufacturing configuration, and business performance: An empirical analysis of the order-winners framework. Journal of Operations Management, 23, 662-675.

Day, G. S. (1990). Market-driven strategy: processes for creating value. New York: The Free Press.

Delery, J. \& Doty, D. H. (1996). Modes of theorizing in strategic human resource management test of universalistic, contingency, and configurational performance predictors. Academy of Management Journal. 39(4): 802-835.

Deshpande, R. \& Webster Jr, F. E. (1989). Organizational culture and marketing: defining the research agenda. Journal of Marketing, 315.

Dillman, D. A. (1978). Mail and Telephone Surveys: The Total Design Method. New York: John Wiley and Sons.

Dombrowski, U., Intra, C., Zahn, T. \& Krenkel, P. (2016). Manufacturing strategy- a neglected success factor for improving competitiveness. Procedia CIRP, 41, 9-14. 


\section{Chen et al.}

Doty, D. H., Glick, W. H. \& Huber, G. P. (1993). Fit, equifinality, and organizational effectiveness: A test of two configurational theories. Academy of Management Journal, 36(6): 1196-1250.

Olson, E. M., Slater, S. F. \& Hult, G. T. M. (2005). The performance implications of fit among business strategy, marketing organization structure, and strategic behavior. Journal of Marketing, 69(3): 49-65.

Fornell, C. \& Larcker, D. E. (1981). Evaluating structural equation models with unobservable and measurement error. Journal of Marketing Research, 18(1): 39-50.

Garvin, D. A. (1993). Manufacturing strategic planning. California Management Review, Summer, 85-106.

Grant, J. H. \& King, W. R. (1982). The logic of strategic planning. Boston: Brown and Company.

Green, Jr., K. W., Whitten D. \& Inman, R. A. (2015). Aligning marketing strategies throughout the supply chain to enhance performance. Industrial Marketing Management, 41, 1008-1018.

Gupta, A. K. (1988). Contingency perspectives on strategic leadership: Current knowledge and future research directions. The executive effect: Concepts and methods for studying top managers, 147-178.

Hair, J. F., Black, W. C., Babin, B. J., Anderson, R. E. \& Tatham, R. L. (2006), Multivariate Data Analysis. New Jersey: Pearson Education Inc.

Hayes, R. \& Wheelwright, S. (1984). Restoring Our Competitive Edge. New York: Wiley and Sons.

Hill, T. (1985). Manufacturing strategy. Basingstoke: Macmillan.

Hill, T. (1995). Manufacturing strategy (2nd ed.). Basingstoke: Macmillan.

Hitt, M. A., Xu, K. \& Carnes, C. M. (2016). Resource based theory in operations management research. Journal of Operations Management, 41, 77-94.

Hunt, S. D. \& Lambe, C. J. (2000). Marketing's contribution to business strategy: market orientation, relationship marketing and the resource-advantage theory. International Journal of Management Reviews, 2(1): 17-43.

Jaworski, B. J. \& Kohli, A. K. (1993). Market orientation: Antecedents and consequences. The Journal of marketing, 57(3): 53-70.

Jüttner, U. S, Christopher, M. \& Godsell, J. (2010). A strategic framework for integrating marketing and supply chain strategies. The International Journal of Logistics Management, 21(1): 104-126.

Karmarkar, U. S. \& Lele, M. M. (2005). The Marketing/Manufacturing Interface: Strategic Issues. In: Chakravarty A.K., Eliashberg J. (eds), Managing Business Interfaces. International Series in Quantitative Marketing, Vol. 16. Springer, Boston, MA.

Katzenbach, J. R. \& Smith, D. K. (1993). The rules for managing cross-functional reengineering teams, Planning Review 21(2): 12-14.

Kim, Y. \& Lee, J. (1993). Beyond mass production. New York: Oxford University Press.

Kotler, P., Keller, K. L., Ang, S. H., Leong, S. M. \& Tan, C. T. (2006). Marketing Management: An Asian Perspective (4th ed.). Singapore: Pearson Prentice Hall, 38-39.

Leong, G. K. \& Ward, L. P. (1994). The six Ps of Manufacturing Strategy. International Journal of Production Management, 15(12): 3245.

Lilien, G. L. \& Weinstein, D. (1984). An international comparison of the determinants of industrial marketing expenditures. Journal of Marketing, 48(Winter): 46-53.

McDougall, P. P., Deane, R. H. \& D'Souza, D. E. (1992). Manufacturing strategy and business origins of new venture firms in the computer and communications equipment industries. Production and Operations Management, 1(1): 53-69.

Miles, R. E. \& Snow, C. C. (1978). Organizational Strategy, Structure, and Process. New York: McGraw-Hill.

Miller, J. G. \& Roth A. V. (1994). A taxonomy of manufacturing strategy. Management Science, 40(3): 285-304.

Mintzberg, H. (1979). The Structure of Organization. New Jersey: Prentice Hall.

O'Leary-Kelly, S.W. \& Flores, B.E. (2002). The integration of manufacturing and marketing/sales decision: Impact of organizational performance. Journal of Operations Management, 20, 221-240.

Olson, E. M., Slater, S. F. \& Hult, G. T. M. (2005). The performance implications of fit among business strategy, marketing organization structure, and strategic behavior. Journal of Marketing, 69, 49-65.

Pagell, M. \& Krause, D. R. (1999). A multiple-method study of environment uncertainty and manufacturing flexibility. Journal of operations Management, 17, 307-325.

Penrose, E. T. (1959). The theory of growth of the firm. New York: Wiley.

Piercy, N. F. (1995). Marketing and strategy fit together in spite of what some management educators seem to think! Management Decision, 33(1): 42-47.

Rebolledo, C. \& Jobin, M. H. (2013). Manufacturing and supply alignment: Are different manufacturing strategies linked to different 
International Journal of Management, Economics and Social Sciences

purchasing practices? International Journal of Production Economics, 146(1): 219-226.

Rhee, M. \& Mehra, S. (2006). Aligning operations, marketing, and competitive strategies to enhance performance: An empirical test in the retail banking industry. Omega, 34, 505-515.

Rho, B., Hahm, Y. S. \& Yu, Y. M. (1994). Improving interface congruence between manufacturing and marketing in industrial-product manufacturers. International Journal of Production Economics, 37(1): 27-40.

Sabherwal, R. \& Chan, Y. E. (2001). Alignment between business and IS strategies: A study of prospectors, analyzers, and defenders. Information Systems Research, 12(1): 11-33.

Schendel, D. \& Hofer, C. (1979). Strategic management: A new view of business policy and planning. Boston, MA: Little, Brown.

Skinner, W. (1969). Manufacturing- missing link in corporate strategy. Harvard Business Review, 47(3): 136-145.

Skinner, W. (1974). The focused factory. Harvard Business Review, 52(3): 114-115.

Slater, S. F. \& Olson, E. M. (2001). Marketing's contribution to the implementation of business strategy: An empirical analysis. Strategic Management Journal, 22(11): 1055-1068.

Sombultawee, K. \& Boon-itt, S. (2018). Marketing-operations alignment: A review of the literature and theoretical background. Operations Research Perspective, 5, 1-12.

St John, C. H. \& Young, S. T. (1992). An exploratory study of pattern of priorities and trade-offs among operations managers.

Production and Operation Management, 1(2): 50-133.

Stobaugh, R. \& Telesio, P. (1983). Match manufacturing policies and practice. Harvard Business Review, 61(2): 111- 120.

Sun, H. \& Hong, C. (2002). The Alignment between Manufacturing and Business Strategies: Its Influence on Business Performance. Technovation, 22(11): 699-705.

Swamidass, P. M. \& Newell, W. T. (1987). Manufacturing strategy, environment uncertainty and performance: a path analytical model. Management Science, 33(4): 509- 524.

Tang, C. S. (2010). A review of marketing-operations interface models: From co-existence to coordination and collaboration. International Journal of Production Economics, 125, 22-40.

Van de Ven, A. H. \& Drazin, R. (1985). The concept of fit in contingency theory: Toward verbal and statistical correspondence. In L. L. Cummings \& B. M. Staw (Eds.), Research in organizational behavior, 7, 333-365.

Varadarajan, P. \& Clark, T. (1994). Delineating the scope of corporate, business and marketing strategy. Journal of Business Research, 31, 93-105.

Varadarajan, P. R. (1999). Marketing strategy: An assessment of the state of the field and outlook. Journal of Marketing Science, 27(2): 120-143.

Venkatraman, N. (1989a). Strategic orientation of business enterprises: The construct, dimesionality, and measurement. Management Science, 35(8): 942-962.

Venkatraman, N. (1989b). The concept of fit in strategy research: toward verbal and statistical correspondence. The Academy of Management Review, 3, 424-444.

Venkatraman, N. (1990). Performance implications of strategic co-alignment: A methodological perspective. Journal of Management Studies, 27(1): 19-41.

Venkatraman, N. \& Camillus, J. C. (1984). Exploring the concept of "fit" in strategic management. Academy of Management Review, 9 , 513-525.

Voss, C. A. (1995). Alternative paradigms for manufacturing strategy. International Journal of Operations \& Production Management, 15(4): 5-16.

Ward, P. T. \& Duray, R. (2000). Manufacturing strategy in context: environment, competitive strategy and manufacturing strategy. Journal of Operations Management, 18(2): 123-38.

Ward, P. T., Bickford, D. J. \& Leong, G. K. (1996). Configurations of manufacturing strategy, business strategy, environment, and structure. Journal of Management, 18, 597-626.

Weir, K. A., Kochhar, A.K., LeBeau, S. A., \& Edgeley, D. G. (2000). Alignment between manufacturing and marketing strategies. Long Range Planning, 33, 831-848.

Wernerfelt, B. (1984). A resource-based view of the firm. Strategic Management Journal, 17(5): 71-180.

Wheelwright, S. C. (1984), Manufacturing strategy: Defining the missing link. Strategic Management Journal, 5, 77-91. 


\begin{tabular}{|c|c|c|c|c|c|c|}
\hline Construct Indicator & Mean & S.D. & $\begin{array}{c}\text { Standardized } \\
\text { Loading }^{\mathbf{a}} \\
\end{array}$ & $\mathbf{I I R}^{\mathbf{b}}$ & $\mathbf{C R}^{\mathrm{c}}$ & $A V E^{d}$ \\
\hline \multicolumn{7}{|c|}{ Marketing Strategy } \\
\hline $\mathrm{Mr}$ & & & & & 0.84 & 0.63 \\
\hline Mr1 & 3.90 & 0.73 & 0.72 & 0.52 & & \\
\hline $\mathrm{Mr} 2$ & 4.08 & 0.62 & 0.80 & 0.64 & & \\
\hline Mr3 & 4.06 & 0.67 & 0.87 & 0.76 & & \\
\hline Seg & & & & & 0.79 & 0.50 \\
\hline Seg1 & 4.06 & 0.6 & 0.70 & 0.49 & & \\
\hline Seg2 & 4.06 & 0.75 & 0.79 & 0.62 & & \\
\hline Seg3 & 3.57 & 0.93 & 0.54 & 0.29 & & \\
\hline Seg4 & 3.86 & 0.68 & 0.75 & 0.60 & & \\
\hline $\mathbf{P i}$ & & & & & 0.80 & 0.57 \\
\hline Pil & 3.98 & 0.71 & 0.72 & 0.52 & & \\
\hline Pi2 & 3.50 & 0.88 & 0.83 & 0.69 & & \\
\hline Pi3 & 3.43 & 0.87 & 0.71 & 0.50 & & \\
\hline $\mathbf{P q}$ & & & & & 0.86 & 0.60 \\
\hline $\mathrm{Pq} 1$ & 4.06 & 0.65 & 0.77 & 0.59 & & \\
\hline $\mathrm{Pq} 2$ & 4.05 & 0.73 & 0.68 & 0.46 & & \\
\hline $\mathrm{Pq} 3$ & 4.12 & 0.65 & 0.84 & 0.71 & & \\
\hline $\mathrm{Pq} 4$ & 4.29 & 0.62 & 0.82 & 0.67 & & \\
\hline $\mathrm{Sq}$ & & & & & 0.91 & 0.68 \\
\hline $\mathrm{Sq} 1$ & 4.26 & 0.62 & 0.83 & 0.69 & & \\
\hline $\mathrm{Sq} 2$ & 4.24 & 0.64 & 0.88 & 0.77 & & \\
\hline $\mathrm{Sq} 3$ & 4.26 & 0.66 & 0.88 & 0.77 & & \\
\hline $\mathrm{Sq} 4$ & 4.26 & 0.69 & 0.82 & 0.67 & & \\
\hline $\mathrm{Sq} 5$ & 4.48 & 0.65 & 0.69 & 0.48 & & \\
\hline Sd & & & & & 0.91 & 0.84 \\
\hline $\mathrm{Sd} 1$ & 3.5 & 0.94 & 0.92 & 0.85 & & \\
\hline $\mathrm{Sd} 2$ & 3.33 & 0.91 & 0.92 & 0.85 & & \\
\hline Madv & & & & & 0.92 & 0.64 \\
\hline Madv1 & 3.1 & 1.09 & 0.85 & 0.72 & & \\
\hline Madv2 & 2.99 & 1.07 & 0.87 & 0.76 & & \\
\hline Madv3 & 2.91 & 1.18 & 0.83 & 0.69 & & \\
\hline Madv4 & 3.25 & 1.12 & 0.83 & 0.69 & & \\
\hline Madv5 & 2.55 & 1.13 & 0.68 & 0.46 & & \\
\hline Madv6 & 3.21 & 1.09 & 0.84 & 0.71 & & \\
\hline Madv7 & 3.68 & 0.81 & 0.65 & 0.42 & & \\
\hline Ps & & & & & 0.83 & 0.50 \\
\hline Ps1 & 3.91 & 0.86 & 0.64 & 0.41 & & \\
\hline Ps2 & 3.6 & 0.96 & 0.64 & 0.41 & & \\
\hline Ps3 & 3.04 & 0.92 & 0.73 & 0.53 & & \\
\hline Ps4 & 3.57 & 0.9 & 0.81 & 0.66 & & \\
\hline Ps5 & 3.55 & 0.79 & 0.70 & 0.49 & & \\
\hline Spp & & & & & 0.86 & 0.75 \\
\hline Spp1 & 3.88 & 0.67 & 0.86 & 0.74 & & \\
\hline Spp2 & 3.6 & 0.93 & 0.87 & 0.76 & & \\
\hline \multicolumn{7}{|c|}{ Manufacturing Strategy } \\
\hline Price & & & & & 1.00 & 1.00 \\
\hline Pril & 3.82 & 0.80 & 1.00 & 1.00 & & \\
\hline Flexibility & & & & & 0.87 & 0.7 \\
\hline Flx 1 & 3.68 & 0.85 & 0.87 & 0.76 & & \\
\hline Vof1 & 4.01 & 0.75 & 0.83 & 0.69 & & \\
\hline Bpl1 & 3.87 & 0.84 & 0.81 & 0.66 & & \\
\hline Quality & & & & & 0.95 & 0.91 \\
\hline Con 1 & 4.19 & 0.68 & 0.96 & 0.92 & & \\
\hline Per1 & 4.16 & 0.73 & 0.96 & 0.92 & & \\
\hline
\end{tabular}


International Journal of Management, Economics and Social Sciences

\begin{tabular}{|c|c|c|c|c|c|c|}
\hline \multicolumn{5}{|l|}{ Delivery } & 0.96 & 0.92 \\
\hline Des 1 & 4.04 & 0.78 & 0.96 & 0.92 & & \\
\hline Des2 & 4.15 & 0.69 & 0.96 & 0.92 & & \\
\hline Service & & & & & 0.82 & 0.61 \\
\hline Ass 1 & 4.18 & 0.70 & 0.64 & 0.41 & & \\
\hline Brd1 & 3.45 & 1.04 & 0.88 & 0.77 & & \\
\hline Adv1 & 3.03 & 1.15 & 0.81 & 0.66 & & \\
\hline \multicolumn{7}{|c|}{ Strategic Orientation } \\
\hline Def & & & & & 0.88 & 0.66 \\
\hline Def1 & 4.16 & 0.59 & 0.82 & 0.67 & & \\
\hline Def2 & 4.17 & 0.56 & 0.81 & 0.66 & & \\
\hline Def3 & 4.16 & 0.69 & 0.82 & 0.67 & & \\
\hline Def4 & 4.19 & 0.64 & 0.79 & 0.62 & & \\
\hline Analy & & & & & 0.91 & 0.76 \\
\hline Analy1 & 4.29 & 0.63 & 0.83 & 0.69 & & \\
\hline Analy2 & 4.15 & 0.60 & 0.92 & 0.85 & & \\
\hline Analy3 & 3.94 & 0.77 & 0.87 & 0.76 & & \\
\hline Proact & & & & & 0.90 & 0.75 \\
\hline Proact1 & 3.68 & 0.83 & 0.79 & 0.62 & & \\
\hline Proact2 & 3.54 & 0.94 & 0.91 & 0.83 & & \\
\hline Proact3 & 3.74 & 0.90 & 0.90 & 0.81 & & \\
\hline Futurity & & & & & 0.92 & 0.86 \\
\hline Fut1 & 3.99 & 0.77 & 0.93 & 0.86 & & \\
\hline Fut2 & 3.91 & 0.79 & 0.93 & 0.86 & & \\
\hline \multicolumn{7}{|c|}{ Business Performance } \\
\hline \multicolumn{2}{|l|}{ Opg } & & & & 0.94 & 0.84 \\
\hline Opg1 & 3.37 & 0.85 & 0.92 & 0.85 & & \\
\hline Opg2 & 3.34 & 0.84 & 0.93 & 0.86 & & \\
\hline Opg3 & 3.34 & 0.88 & 0.90 & 0.81 & & \\
\hline Opp & & & & & 0.94 & 0.77 \\
\hline Opp1 & 3.29 & 0.83 & 0.80 & 0.64 & & \\
\hline Opp2 & 3.27 & 0.84 & 0.94 & 0.88 & & \\
\hline Opp3 & 3.29 & 0.86 & 0.94 & 0.88 & & \\
\hline Opp4 & 3.35 & 0.83 & 0.91 & 0.83 & & \\
\hline Opp5 & 3.53 & 0.86 & 0.79 & 0.62 & & \\
\hline $\begin{array}{ll}\text { Note: } & \text { a. } \\
& \text { b. } \\
& \text { c. } \\
& \text { d. } \\
& \text { e. }\end{array}$ & $\begin{array}{l}\text { gnifican } \\
(\mathrm{IIR})=( \\
=\left(\Sigma \mathrm{L}_{\mathrm{i}}\right)^{2} \\
\text { d (AVE) } \\
\text { Seg: Seg } \\
\text { t; Madv } \\
\text { lalysis; } \mathrm{P}\end{array}$ & $\begin{array}{l}0.05 \text { lev } \\
\text { dized lo } \\
+\Sigma \operatorname{Var}( \\
\left(\Sigma \mathrm{L}_{\mathrm{i}}^{2}+\Sigma\right. \\
\text { on/targe } \\
\text { rtising; } \\
\text { roactive }\end{array}$ & $\begin{array}{l}\text { ) } \\
\text { i: Prod } \\
\text { ersonal } \\
\text { Opg: Gr }\end{array}$ & $\begin{array}{l}\text { Pq: Pr } \\
\text { Support } \\
\text { fitabilit }\end{array}$ & uality; & $\begin{array}{l}\text { rvice quality; } \\
\text { process; Def: }\end{array}$ \\
\hline
\end{tabular}

Table 1: Scale Properties for the Measurement Model 


\begin{tabular}{|c|c|c|c|c|c|c|c|c|c|c|c|c|c|c|c|c|c|c|c|c|}
\hline Variable & 1 & 2 & 3 & 4 & 5 & 6 & 7 & 8 & 9 & 10 & 11 & 12 & 13 & 14 & 15 & 16 & 17 & 18 & 19 & 20 \\
\hline 1. $\mathrm{Mr}$ & 0.79 & & & & & & & & & & & & & & & & & & & \\
\hline 2.Seg & 0.50 & 0.71 & & & & & & & & & & & & & & & & & & \\
\hline 3.Pi & 0.43 & 0.44 & 0.75 & & & & & & & & & & & & & & & & & \\
\hline 4.Pq & 0.44 & 0.41 & 0.31 & 0.78 & & & & & & & & & & & & & & & & \\
\hline 5.Sq & 0.43 & 0.40 & 0.37 & 0.69 & 0.82 & & & & & & & & & & & & & & & \\
\hline 6.Sd & 0.33 & 0.37 & 0.44 & 0.34 & 0.38 & 0.92 & & & & & & & & & & & & & & \\
\hline 7.Madv & 0.30 & 0.39 & 0.35 & 0.07 & 0.16 & 0.54 & 0.79 & & & & & & & & & & & & & \\
\hline 8.Ps & 0.21 & 0.28 & 0.22 & 0.30 & 0.23 & 0.20 & 0.29 & 0.70 & & & & & & & & & & & & \\
\hline 9.Spp & 0.37 & 0.47 & 0.32 & 0.42 & 0.36 & 0.34 & 0.43 & 0.55 & 0.86 & & & & & & & & & & & \\
\hline 10.Price & 0.19 & 0.18 & 0.19 & 0.25 & 0.27 & 0.24 & 0.15 & 0.06 & 0.33 & NA & & & & & & & & & & \\
\hline 11.Flexibility & 0.24 & 0.27 & 0.43 & 0.37 & 0.41 & 0.30 & 0.23 & 0.30 & 0.40 & 0.50 & 0.83 & & & & & & & & & \\
\hline 12.Quality & 0.35 & 0.29 & 0.31 & 0.53 & 0.56 & 0.33 & 0.17 & 0.21 & 0.42 & 0.44 & 0.50 & 0.96 & & & & & & & & \\
\hline 13.Delivery & 0.43 & 0.32 & 0.29 & 0.43 & 0.52 & 0.25 & 0.26 & 0.10 & 0.40 & 0.38 & 0.51 & 0.66 & 0.96 & & & & & & & \\
\hline 14.Service & 0.39 & 0.42 & 0.42 & 0.28 & 0.33 & 0.50 & 0.67 & 0.40 & 0.47 & 0.25 & 0.44 & 0.35 & 0.43 & 0.78 & & & & & & \\
\hline 15.Def & 0.55 & 0.39 & 0.28 & 0.54 & 0.52 & 0.22 & 0.20 & 0.33 & 0.44 & 0.23 & 0.39 & 0.53 & 0.46 & 0.28 & 0.81 & & & & & \\
\hline 16.Analy & 0.49 & 0.40 & 0.35 & 0.61 & 0.60 & 0.37 & 0.14 & 0.35 & 0.43 & 0.33 & 0.44 & 0.42 & 0.39 & 0.29 & 0.65 & 0.87 & & & & \\
\hline 17.Proact & 0.37 & 0.22 & 0.45 & 0.42 & 0.43 & 0.34 & 0.33 & 0.35 & 0.42 & 0.17 & 0.57 & 0.46 & 0.45 & 0.43 & 0.38 & 0.36 & 0.86 & & & \\
\hline 18.Futurity & 0.51 & 0.32 & 0.37 & 0.41 & 0.49 & 0.33 & 0.27 & 0.36 & 0.50 & 0.30 & 0.39 & 0.51 & 0.58 & 0.42 & 0.48 & 0.49 & 0.52 & 0.93 & & \\
\hline 19.Opg & 0.34 & 0.32 & 0.31 & 0.30 & 0.34 & 0.31 & 0.29 & 0.23 & 0.41 & 0.41 & 0.42 & 0.36 & 0.37 & 0.31 & 0.40 & 0.42 & 0.44 & 0.48 & 0.91 & \\
\hline 20.Opp & 0.32 & 0.32 & 0.29 & 0.20 & 0.26 & 0.27 & 0.25 & 0.11 & 0.30 & 0.39 & 0.37 & 0.29 & 0.32 & 0.26 & 0.31 & 0.32 & 0.28 & 0.38 & 0.75 & 0.87 \\
\hline
\end{tabular}

Diagonal elements (in bold) represented the square root of Average Variance Extracted $(=\Sigma \mathrm{Li} 2 /(\Sigma \mathrm{Li} 2+\Sigma \mathrm{V}$ ar(Ei))), while off-diagonal elements were represented by the correlation among constructs. For discriminant validity, diagonal elements should be larger than off-diagonal elements.

Table2: Intercorrelations and AVEs 


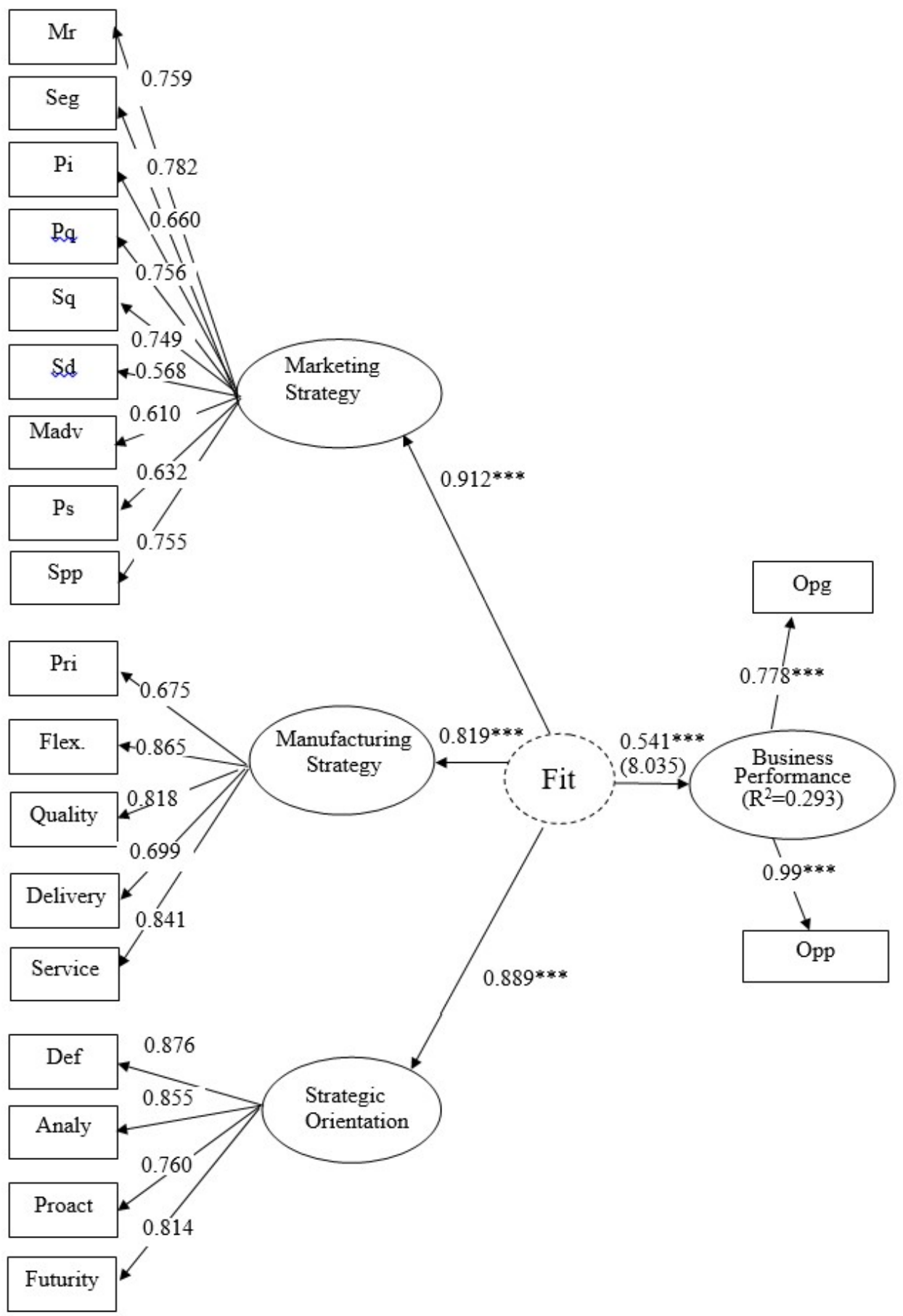

Figure 1. The Result of the Fit Model 